\title{
A GENETIC LINKAGE IN CICER ARIETINUM L.
}

\author{
N. R. BHAT and G. P. ARGIKAR
}

Crop Research Section Department of Agriculture, Bombay State

Received 2.v.50

Though as many as seven pairs of chromosomes have been found in Cicer (Dombrowsky-Sludsky, 1927, and Rau, 1929), not a single genetic linkage has been reported so far. Pimplikar (1943) refers to the association observed between flower colour and seed coat colour as perfect linkage. However, from the results presented by him, it appears almost certain that it is a case of pleiotropy and not linkage. The association is obviously due to gene " $\mathrm{P}$ " which has been assumed to be common to both the pink-flowered and white-flowered parents, used in his cross. As the various colours of the flower and the seed coat are but the products of interaction of this gene with the other genes involved, pleiotropy has the semblance of linkage in the results that he obtained. It is proposed to give in this paper an account of a genetic linkage, not improbably a linkage group, discovered in the course of work done at the Crop Breeding Station, Bailhongal, State of Bombay.

In the year 1947, a cross was made between the mutant alternifolia (Argikar, I950, 7. Ind. Bot. Soc., in press) and a plant of the "Dohad" type which possessed a normal, opposite leaflet arrangement. Incidentally, the cross involved also two other contrasting characters, namely (I) branching habit, and (2) period of maturity of which the former has been already reported to be monogenic (Ramanatha Aiyer et al., 1937). The two parents possessed the characters in the following manner :-

\begin{tabular}{|c|c|c|c|}
\hline Parent & $\begin{array}{c}\text { Branching } \\
\text { habit }\end{array}$ & $\begin{array}{c}\text { Leaflet } \\
\text { arrangement }\end{array}$ & $\begin{array}{c}\text { Period of } \\
\text { maturity }\end{array}$ \\
\hline alternifolia & Umbrella-shaped (u)* & alternate (al) & $\begin{array}{c}\text { Early (E) } \\
\text { about 97 days } \\
\text { Late (e) } \\
\text { "Dohad "type }\end{array}$ \\
\hline Basal (U) & Opposite (AL) & ir days \\
\hline
\end{tabular}

* Letters within the brackets have been adopted as symbols for the characters, in this paper.

The $F_{1}$ plant had basal branching, opposite leaflet arrangement and was early to mature. 
The $\mathrm{F}_{2}$ progeny consisted, unfortunately, of only 69 plants resulting from the seed of only one $F_{1}$ plant. The phenotypic segregation was of the following kind :-

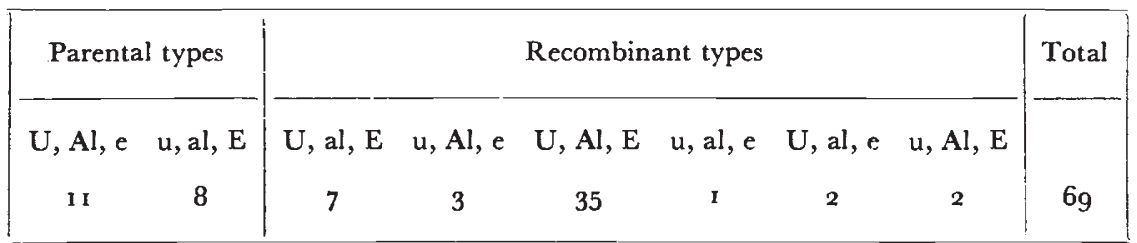

In spite of the small number, the segregation for the individual characters, which is in all cases monogenic, has been satisfactory as will be seen from the values of probabilities for goodness of fit.

\begin{tabular}{|l|c|c|}
\hline Factor & $\chi^{2}$ & $\mathrm{P}$ \\
\hline U-u & 0.82 & $0 \cdot 3-0 \cdot 5$ \\
Al-al & $0 \cdot 13$ & $0 \cdot 7-0 \cdot 8$ \\
E-e & 0.014 & $0.9-0 \cdot 95$ \\
\hline
\end{tabular}

The nature of the two-factor segregation is shown below :-

\begin{tabular}{|c|c|c|}
\hline Factors taken together & $\chi_{{ }_{\mathrm{L}}}$ & $\mathbf{P}$ \\
\cline { 1 - 3 } U-u and Al-al & $1 \mathrm{I} \cdot 63$ & $0 \cdot 0 \mathrm{I}$ \\
Al-al and E-e & $0 \cdot 85$ & $0 \cdot 3-0 \cdot 5$ \\
U-u and E-e & $0 \cdot 13$ & $0 \cdot 7-0 \cdot 8$ \\
\hline
\end{tabular}

It will be seen from the statistics given above that the probabilities are high for the first pair of characters to be linked. In the case of the second pair, there are alternative possibilities of the factors being either very loosely linked or of their being independent of each other, a definite conclusion being impossible with such a small number of plants. The segregation of the third pair is such as to support either of the above alternatives, the view of loose linkage being admissible if the order of the three factors is assumed to be U-Al-E.

The percentage of recombination between the factors, $\mathrm{U}$ and $\mathrm{Al}$, estimated by the Scoring Method (Fisher, 1946; Bhat, 1948) is 23.85 . It the factor, $\mathrm{E}$, be loosely linked to these two, the recombinations possible in the segments, Al-E and U-E would be of the order of $4^{1} \cdot 00$ per cent. and $5^{\circ} .00$ per cent. respectively, on the basis of segregation observed amongst the 69 plants. On making adjustments 
with Kosambi's formula, which is applicable in this case, the possible estimates and map-lengths are as below :-

\begin{tabular}{|c|c|c|c|}
\hline Segment & $\begin{array}{c}\text { Recombination } \\
\text { per cent. }\end{array}$ & $\begin{array}{c}\text { Map-length in } \\
\text { centimorgans }\end{array}$ & $\begin{array}{c}\chi^{2} \text { for agreement } \\
\text { with } \\
\text { Kosambi's formula }\end{array}$ \\
\hline U-Al & $24 \cdot 17$ & $26 \cdot 37$ & $0 \cdot 003$ \\
Al-E & 43.07 & 64.93 & $0 \cdot 044$ \\
U-E & 47.47 & $91 \cdot 30$ & $0 \cdot 373$ \\
\hline
\end{tabular}

The perfect agreement of the data with Kosambi's formula shows that it is not improbable that all the three factors studied in this case are situated on the same chromosome.

Another possible method of testing whether the factor for flowering duration is or is not linked with the two other factors is to test the agreement of the observed frequencies of phenotypes with those to be expected on the basis of ( 1 ) loose linkage and (2) independence. This is done below :-

\begin{tabular}{|c|c|c|c|c|c|c|c|c|c|}
\hline & \multicolumn{2}{|c|}{$\begin{array}{l}\text { Parental } \\
\text { types }\end{array}$} & \multicolumn{6}{|c|}{$\begin{array}{l}\text { Types resulting from recombination } \\
\text { in segments }\end{array}$} & \multirow{3}{*}{$\begin{array}{l}\text { Total } \\
\chi^{2} \\
\text { (7 d.f.) }\end{array}$} \\
\hline & \multirow{2}{*}{$\mathrm{U}, \mathrm{Al}, \mathrm{e}$} & \multirow{2}{*}{$\mathrm{u}, \mathrm{Al}, \mathrm{E}$} & \multicolumn{2}{|c|}{ I } & \multicolumn{2}{|c|}{ II } & \multicolumn{2}{|c|}{ I and II } & \\
\hline & & & $\mathrm{U}, \mathrm{al}, \mathrm{E}$ & $\mathrm{u}, \mathrm{Al}, \mathrm{e}$ & $\mathrm{U}, \mathrm{Al}, \mathrm{E}$ & $u, a l, e$ & $\mathrm{U}, \mathrm{al}, \mathrm{e}$ & $\mathrm{u}, \mathrm{Al}, \mathrm{E}$ & \\
\hline Observed & I I & 8 & 7 & & & $\mathbf{I}$ & 2 & 2 & $\ldots$ \\
\hline $\begin{array}{l}\text { Expected on the basis } \\
\text { of "E" being } \\
\text { linked to } \mathrm{U} \text { and } \mathrm{Al}\end{array}$ & $12 \cdot 8$ & $8 \cdot 08$ & $5 \cdot 97$ & $1 \cdot 88$ & $32 \cdot 86$ & $\mathrm{I} \cdot 84$ & $1 \cdot 36$ & $5 \cdot 45$ & $\cdots$ \\
\hline$\chi^{2}$ for agreement & $0 \cdot 114$ & 0.001 & $0 \cdot 178$ & $0.66_{7}$ & $0 \cdot 139$ & 0.383 & 0.301 & $2 \cdot 184$ & 3.967 \\
\hline $\begin{array}{l}\text { Expected on the basis } \\
\text { of independence of } \\
\text { " } E \text { " }\end{array}$ & $I I \cdot I 2$ & $7 \cdot 47$ & $5 \cdot 46$ & $r \cdot 82$ & $33 \cdot 35$ & $2 \cdot 49$ & $1 \cdot \breve{8}_{2}$ & $5 \cdot 46^{x}$ & $\ldots$ \\
\hline$\chi^{2}$ for agreement & 0.001 & 0.037 & $0.43 \mathrm{I}$ & 0.762 & $0.08_{2}$ & $0.89^{2}$ & 0.017 & $2 \cdot 197$ & $4 \cdot 4^{19}$ \\
\hline
\end{tabular}

Even the above test leaves the question undecided, though the observed frequency of the critical triple recessive phenotype $u$, al, e, agrees better with that to be expected on the hypothesis of linkage rather than of independence. No definite conclusion can, therefore, be drawn until either about 2960 plants, required for discriminating the linkage between $\mathrm{Al}$ and $\mathrm{E}$ from independence, are bred or till a factor between the two is discovered.

\section{SUMMARY}

A linkage of 23.85 per cent. is reported between the factor for branching habit and that for leaflet arrangement in Cicer arietinum L. 
This is the first genetic linkage detected so far in the species. It is not improbable that the factor for period of maturity is also linked to these two.

\section{REFERENCES}

ARGIKAR, G. P. $\quad$ 1950. Some unreported mutations and segregates in Bengal gram (Cicer arietinum L.), r950. J. ind. Bot. Soc. (in press).

AYYAR, V. R., AND BALASUBRAMANYAM, R. 1937. Inheritance of branching habit in gram (Cicer arietinum L.). Madras Agric. 7., 25, 1 05-1 06.

DOMBROWSKY-SLUDSKY. 1927. Quoted by Hector, J. M. Introduction to the Botany of Field Crops. II. Noncereals, p. 780. Johannesburg, South Africa : Central News Agency, Ltd.

FISHER, R. A. I946. A system of scoring linkage data with special reference to pied factors in mice. Amer. Nat., 80, 568-578.

PIMPLIKAR, E. D. 1943. Studies in the grams of C.P. and Berar. II. The inheritance of some characters in gram (Cicer arietinum L.). Nagpur Agric. Coll. Mag., 18, 27-40.

RAU, N. s. 1929. Further contributions to the cytology of some crop plants of South India. 7. Ind. Bot. Soc., 8, $201-206$. 